\title{
POLYMERIC COMPOSITE MATERIALS OF TRIBOTECHNICAL PURPOSE WITH A HIGH LEVEL OF PHYSICAL, MECHANICAL AND THERMAL PROPERTIES
}

\author{
Oleh Kabat ${ }^{1,2,}$, Volodymyr Sytar $^{1}$, Oleksii Derkach ${ }^{2}$, Kostyantyn Sukhyy $^{1}$
}

https://doi.org/10.23939/chcht15.04.543

\begin{abstract}
Polymeric composites (PC) of tribological applications with a high level of physical, mechanical and thermal properties based on aromatic polyamide and silica gel have been developed. Regularities have been obtained that describe the effect of the filler content in PC on the friction coefficient, temperature on the friction surface and the intensity of linear wear rate of the studied PC-steel friction pair. It was found that the optimal silica gel content in the polymer matrix is $10 \mathrm{wt} \%$. The morphology of the steel surface of friction after friction interaction with PC based on aromatic polyamide and silica gel was studied. The formation of an antifriction film on the steel surface of friction was discovered, which contributes to a decrease in the friction coefficient, temperature on the friction surface, and the linear wear intensity of the studied PC. The influence of the load and sliding speed on the main tribotechnical characteristics of the PC-steel friction pair has been studied. Mathematical laws were derived that describe the influence of the main external factors (load and sliding speed) on the friction coefficient and intensity of linear wear rate of the studied friction pair. Physical, mechanical and thermal investigations of the developed PC were carried out and it was found that the introduction of $10 \mathrm{wt} \%$ silica gel contributes to their 5-10\% increase.
\end{abstract}

Keywords: friction unit, aromatic polyamide, silica gel, polymer composite, tribological properties, physical and mechanical properties.

\section{Introduction}

In modern engineering polymer composites (PC) are becoming more widespread as materials for parts of friction units (rolling and sliding bearings, face seals,

\footnotetext{
${ }^{1}$ Ukrainian State University of Chemical Technology,

8, Gagarina Ave., Dnipro City, Ukraine;

Amber_UDHTU@i.ua

${ }^{2}$ Dnipro State Agrarian and Economic University,

25, SerhiyYefremov St., Dnipro City, Ukraine

(C) Kabat O., Sytar V., Derkach O., Sukhyy K., 2021
}

guide bushes, etc.). Thanks to the ability to work without oiling or in boundary lubrication mode, in chemical active and abrasive environments, under the influence of alternating loads PC actively displace "traditional" materials, that are used in friction units, like metals and their alloys. The using of PC in friction units allows to significantly accelerate and simplify the process of creations of modern high-techmachines (solar powered aircraft "Solar Impulse SI2", reusable "SpaceShipTwo" spaceflight system, spaceship"Falcon 9", electric car "Tesla) that work in extreme conditions.

However the disadvantages of PC include their relatively low level of strength and heat resistance do not allow to use them in even more machine units.

One of the methods for solving the problem is the creation of PC of tribological purpose with the high level of physical, mechanical and thermophysical properties. To solve this problem it is necessary to select, as a polymer matrix, a thermostable polymer of constructional purpose and fill it with a material that can significantly reduce its friction and wear during frictional interaction with steel while maintaining the level of properties of the original polymer matrix.

The most common polymer matrices with a high level of physical, mechanical and thermal properties include aromatic polyamides, polyimides, polyarylates, polysulfones and phenolic resins.

Aromatic polyamides are one of the most durable and heat resistant polymers. In terms of strength they approach steels, while they remain unchanged at temperatures up to $573 \mathrm{~K}$. High radiation and chemical resistance allows the use of parts made of aromatic polyamides in active environments. They are characterized by high wear resistance during frictional interaction with steel $[9,10]$. The main disadvantages of these polymers are their rather high price and difficulties in processing into products using highly productive methods (extrusion, injection molding).

Polyimides are polymers with a high level of strength, which details retain their performance at temperatures up to $573 \mathrm{~K}$ and withstand short-term loads 
at temperatures up to $773 \mathrm{~K}$ [11]. The friction coefficient of these polymers during frictional interaction with steel, unlike most polymers, decreases with increasing temperature to $573 \mathrm{~K}$ [12]. One of the main disadvantages of polyimides is their high price and the complexity of processing into products.

Polyarylates are polymers with a fairly high level of physical, mechanical and thermal properties [13]. They withstand shock loads and vibrations; have high wear resistance and a low coefficient of friction during frictional interaction with steel. The maximum temperature of their operation approaches $573 \mathrm{~K}$ [14]. High chemical resistance allows the use of these polymers in friction units operating in active media. The main disadvantages of polyarylates include the impossibility of their processing into products by highly productive methods (extrusion, injection molding) due to the presence of rigid chain macromolecules and the coincidence of the melting and destruction temperatures.

Polysulfones are thermoplastics with a high level of heat resistance, physical and mechanical properties [15]. Details from these polymers can be used in friction units of machines and mechanisms at temperatures up to $473 \mathrm{~K}$ without significant deterioration of their properties. The disadvantages of these polymers include their high cost and hygroscopic properties of based materials.

Phenolic resins are fairly cheap materials with a high level of physical, mechanical and thermal properties [16]. Such details retain their performance at temperatures up to $673 \mathrm{~K}$ and in some cases up to $873 \mathrm{~K}$ [17]. Among the disadvantages of phenolic resins, one should note their low level of environmental safety both during processing into a product and the product itself and a low level of tribological properties during friction on steel.

From the presented polymers the aromatic polyamides are the most promising for creating PC for tribotechnical applications with a high level of physical, mechanical and thermal properties. Their strength reaches $230 \mathrm{MPa}$, heat and heat resistance are 563 and $623 \mathrm{~K}$, respectively. The main disadvantage of these polymers (relatively high values of the friction coefficient during frictional interaction with steel) is eliminated by filling them with materials that contribute to the improvement of the friction process.

The filler for creating PC for tribotechnical purposes with a high level of physical, mechanical and thermal properties should not only improve the tribotechnical properties of the PC-steel friction pair, while maintaining high values of heat and heat resistance of the polymer matrix, but also satisfy the following requirements: low cost, prevalence in nature and environmental safety [18].
Traditional fillers for the creation of tribological applications PC (graphite, molybdenum disulfide, boron nitride, talc) are layered materials that, when introduced into the polymer matrix, improve the tribotechnical properties of the PC-steel friction pair $[19,20]$, but significantly reduce strength level of composites. PC filled with layered fillers are characterized by a significant anisotropy of properties and in most cases are not able to withstand a high level of static, dynamic and alternating loads. Fibrous materials (organic and inorganic fibers) used as a filler can improve the level of physical and mechanical properties of the polymer matrix and reduce its friction and wear during frictional interaction with steel $[21,22]$. However, these materials are of high cost and significantly complicate the technology of processing PC into products.

Therefore, to create PC of tribotechnical purposes with a high level of physical, mechanical and thermal properties, it is necessary to use dispersed (non-layered) fillers that can strengthen the polymer matrix and reduce its surface energy. Such material is silicon dioxide of various modifications. These materials are inexpensive and non-deficient fillers, which due to the developed surface and active "silanol" groups are capable of physical and chemical interaction with polymer molecules when they are jointly processed into products.

It was shown in $[23,24]$ that the use of silicon dioxide of various modifications as a filler for the creation of PC allows not only to improve the tribotechnical characteristics of the PC-steel friction pair, but also significantly increase the strength and heat resistance of PC. Among a large number of silicon dioxide varieties, the most widely used polymers fillers are synthetic amorphous materials of the grades: white-soot, aerosil, and silica gel. However, based on previous studies [25], it was established that silica gel has the best reinforcing effect on the polymer matrix and can improve its strength characteristics, increase heat resistance by $10-15 \%$, and reduce the coefficient of friction and $\mathrm{PC}$ wear during frictional interaction with steel by $1.5-2$ and $8-10$ times, respectively.

Based on the above, the main task of this work is to develop PC of tribotechnical purposes with a high level of physical, mechanical and thermal properties.

\section{Experimental}

\subsection{Materials}

An aromatic polyamide (brand phenylon C1) was used as a polymer matrix. It is a polymer obtained by polycondensation by the interaction of diamines $(\mu$ - and $n$ - 
phenylenediamine) with isophthalic acid dichlorohydride. In its original form phenylon $\mathrm{C} 1$ is produced in the form of a press material with an average particle size of 20 40 microns and is processed into products by compression pressing in molds with heating.

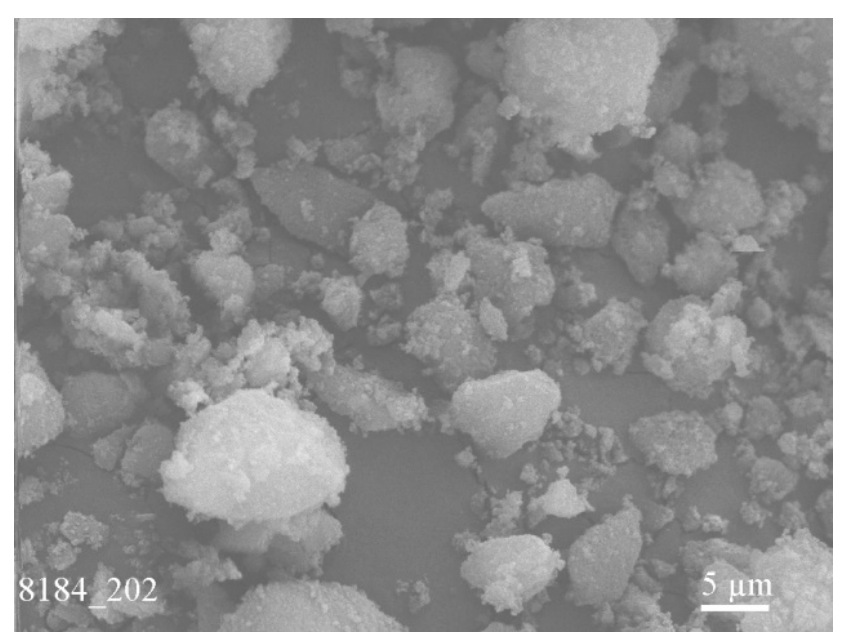

a)
Dehydrated and crushed gel of silicic acid (silica gel) was used as a filler; it was obtained by precipitation from an aqueous-alkaline solution of sodium metasilicate. The final filler has a developed surface with an average particle size of $5-10 \mu \mathrm{m}$ (Fig. 1).

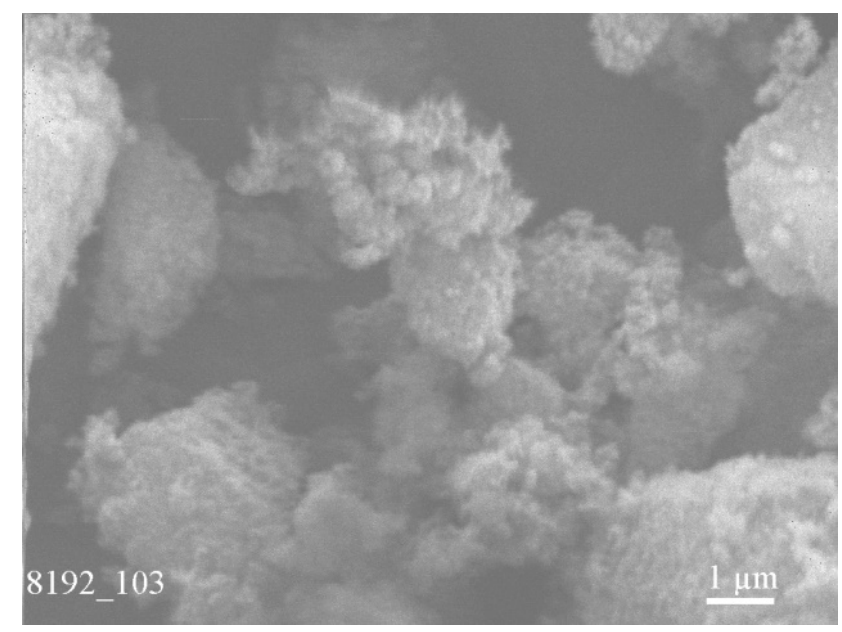

b)

Fig. 1. Photos of silica gel: magnification of $400 \times(a)$ and $2000 \times$ (b)

\subsection{Methods of Obtaining PC}

Research samples were obtained according to the following scheme: combination of polymer with a filler; tableting; drying tablets; compression molding in heated molds; cooling.

Aromatic polyamide was combined with the silica gel in a high-speed mechanical mixer with a complex shape of the blades, which provide the high quality mixing of the starting components. The resulting polymer composition was tableted in molds and dried in an oven at a temperature of $453 \mathrm{~K}$ for $1 \mathrm{~h}$. Samples were prepared using a compression molding in heated molds at a temperature of $613 \mathrm{~K}$ and a pressure of $40 \mathrm{MPa}$. Their cooling was carried out at a pressing pressure to a temperature of $493 \mathrm{~K}$ [8].

\subsection{Research Methods}

The tribological properties of the initial polymer matrix and PC based on it during a frictional interaction with steel were determined on a "2070 CMT-1" machine under friction without lubrication. The morphology of the friction surfaces was obtained using an electron microscope Superprobe -733 (Jeol). The roughness of the steel surface $(R a)$ of friction was measured in accordance with the state standard on a profilometer "Model 296". The microhardness $(H V)$ of the friction steel surface was measured in accordance with the state standard on a microhardness meter "PMT-3".

The density $(\rho)$ of the materials was determined using the hydrostatic weighing method in accordance with ISO 1183-1. The stresses at the yield strength $\left(\sigma_{y}\right)$ and the elastic modulus $(E)$ under compression were determined in accordance with ISO 604 on a Heckert FP 100/1 universal tensile testing machine. The hardness $(H)$ of the materials was determined by the method of indentation of the ball on the hardness tester "2013 TShSP" in accordance with ISO-2039-1. The temperature heat resistance of the starting polymer and PC based on it was determined by the method of thermogravimetric analysis in accordance with ISO-11358 on a Q1500D derivatograph. Vicat softening temperature $\left(T_{V C}\right)$ of the starting polymer and PC based on it was determined according to ISO $1183-1$ at FWV-633/10 device.

\section{Results and Discussion}

To create PC of tribotechnical applications with a high level of physical, mechanical and thermal properties it is important to study the filler effect on a polymer matrix based on aromatic polyamide of the phenylon $\mathrm{C} 1$ brand. Polymer composites with a filler content up to $30 \mathrm{wt} \%$ were obtained in accordance with previous studies $[25,26]$. 


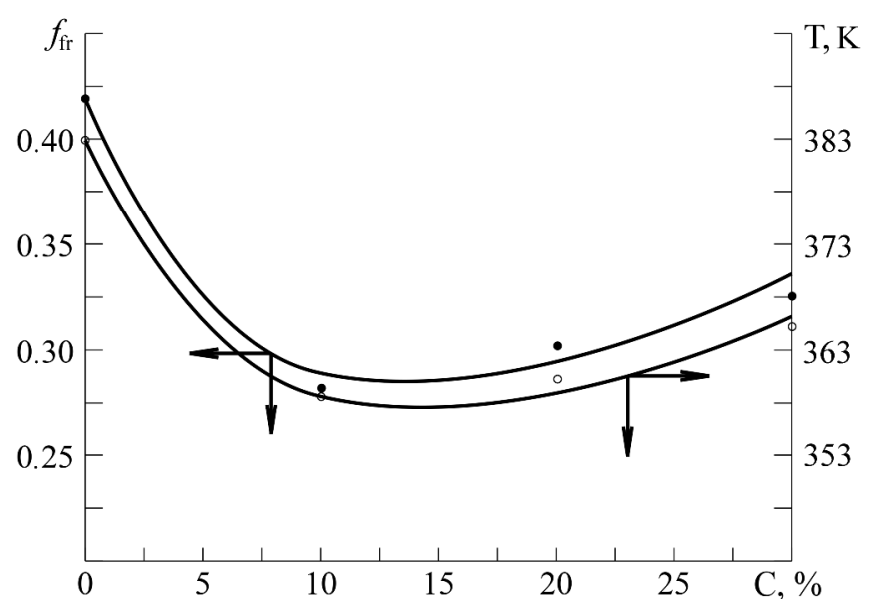

a)

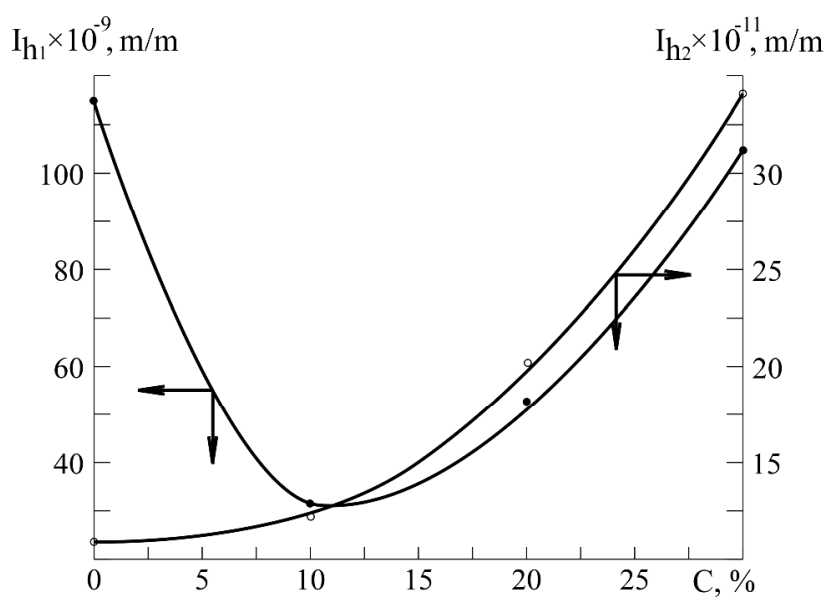

b)

Fig. 2. Dependences of the friction coefficient $\left(f_{\mathrm{fr}}\right)$ and temperature $(\mathrm{T})$ on the friction surface (a) and the intensity of linear wear rate (b) of PC $\left(\mathrm{I}_{\mathrm{h} 1}\right)$ and steel sample $\left(\mathrm{I}_{\mathrm{h} 2}\right)$ on the silica gel content in PC during its frictional interaction with steel (friction modes: load $P=1 \mathrm{MPa}$, sliding speed $V=0.75 \mathrm{~m} / \mathrm{s}$ )

Due to the fact that these materials are developed for friction units of machines and mechanisms, it was necessary to conduct tribological studies to establish the optimal filler content in the polymer. The research results are shown in Fig. 2. Based on the investigations it was found that the introduction of silica gel into the composition of the aromatic polyamide allows to improve the tribological properties of the PC developed during friction on steel. Thus the friction coefficient and temperature on the friction surface decreased by $20-45 \%$, and the linear wear intensity of the developed PC is $4-6$ times lower than in the initial polymer. With an increase in the content of silica gel in aromatic polyamide, an increase in the wear rate of the steel sample is observed, which is associated with the abrasive action of the solid filler on steel. In this case, it is worth noting the non-linear nature of the increase in this parameter. Thus, the intensity of linear wear rate of the steel sample of the friction pair during frictional interaction with silica gel content $\mathrm{PC}$ up to $10 \%$ is significantly lower than that of materials with $10-30 \%$ filler content and its values slightly exceed the same parameter for an unfilled polymer.

The obtained dependences of the main tribotechnical characteristics of the PC-steel friction pair have extremes in the region of $10 \%$ silica gel content in aromatic polyamide. This material has minimum values of the friction coefficient, temperature on the friction surface and the intensity of linear wear during frictional interaction with steel. Based on this, it was found that the optimal filler content in the polymer is $10 \mathrm{wt} \%$.

The improvement of the tribological properties of the developed PC in comparison with the initial polymer during frictional interaction with steel is a consequence of the influence of the filler both on the PC and on its friction nature. To establish its mechanism the morphology and structure of the steel friction surface were studied after frictional interaction with the starting aromatic polyamide and PC based on it (Fig. 3).

Based on microphotographs it can be concluded that the friction surface of a steel sample after friction interaction with aromatic polyamide (Fig. 3a) and PC based on it filled with silica gel (Fig. 3b) have both morphological and structural differences.

Morphological differences are associated with a change in the geometry of the steel surface during frictional interaction with the original and filled polymer. Studies of the arithmetic mean deviation of the height of the protrusions and depressions (surface roughness parameter $R a$ ) show (Fig. 4) that with an increase in the filler content in the polymer, the roughness of the steel surface for the studied friction pairs varies from 0.260 to $0.272 \mu \mathrm{m}$.

In this case we should pay attention to the extreme nature of the obtained dependence. A more intense change in the roughness of the steel surface is observed during frictional interaction with the filler content of PC from 0 to $10 \mathrm{wt} \%$. A further increase in the filler content in the polymer (up to $30 \mathrm{wt} \%$ ) does not lead to a significant change in the roughness of the steel sample. Therefore it is a consequence of the establishment of a stable friction regime during the interaction of the steel sample with PC with $10 \%$ filler content. 


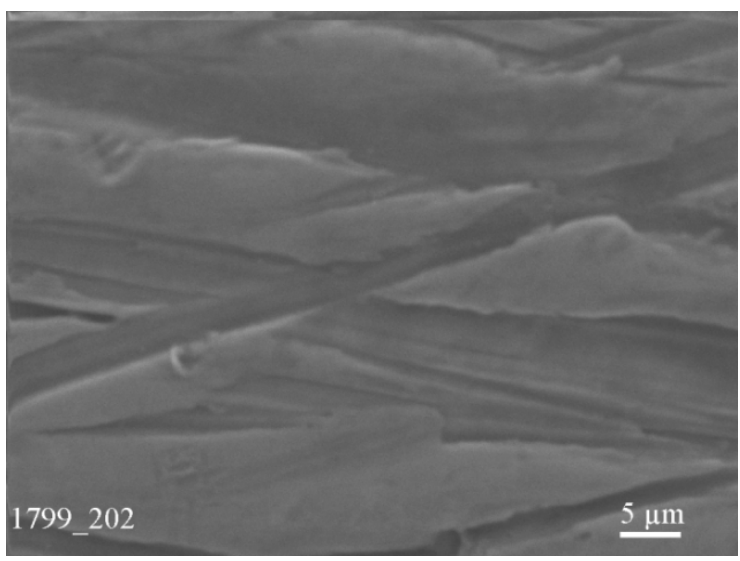

a)

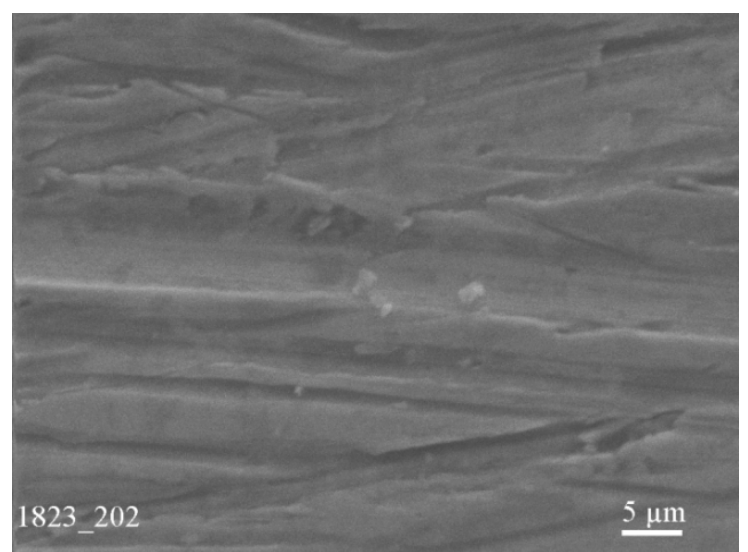

b)

Fig. 3. Microphotographs of the steel surface after friction interaction with the original aromatic polyamide (a) and based on it PC filled with silica gel (b)

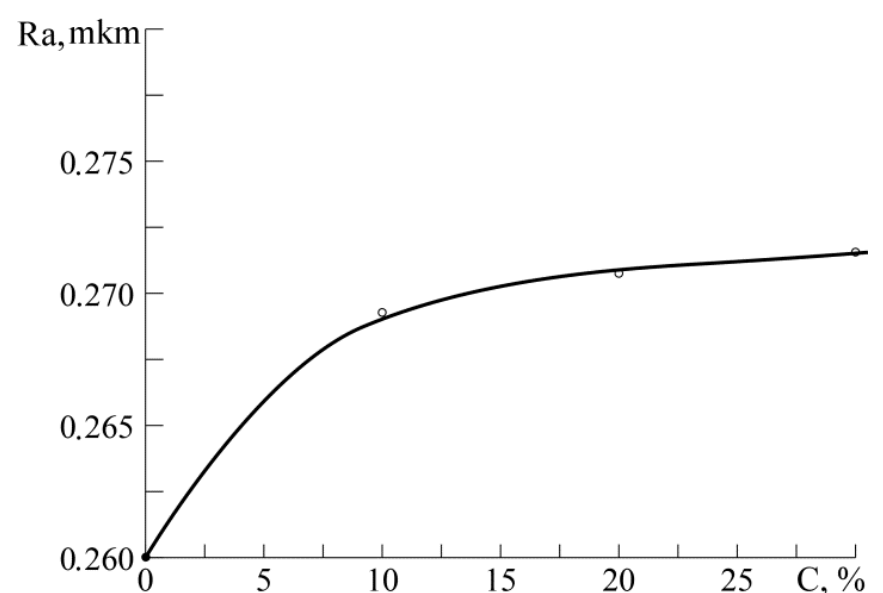

a)

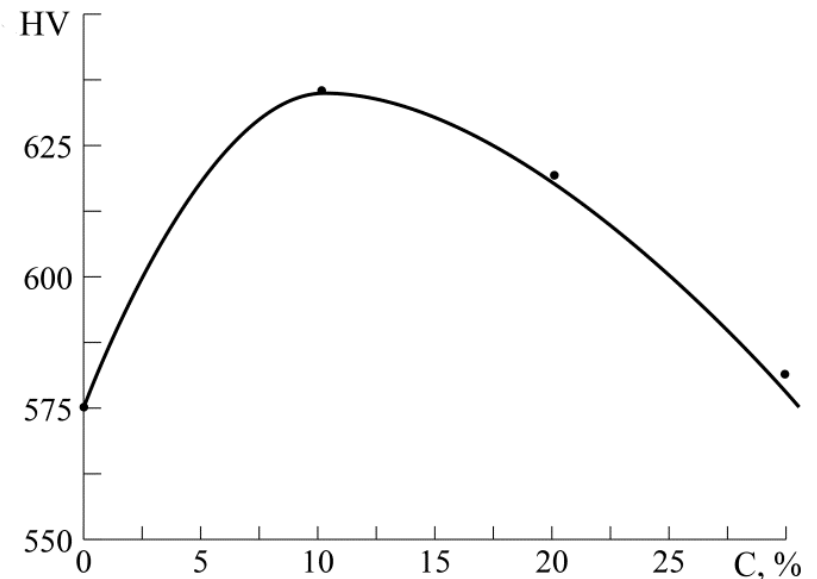

b)

Fig. 4. Dependences of roughness (a) and microhardness (b) on the content of silica gel in PC of PC-steel friction pair

Structural differences are due to the appearance of "transfer islands" on the steel friction surface upon interaction with a filled polymer (Fig. 3b), which are formed as a result of tribochemical reactions taking place in the friction zone. Due to the fact that silica gel is involved in these reactions, the formed "transfer islands" are likely to be cermet compounds that contribute to a change in the friction pattern of the materials under study by reducing the surface activity of the steel sample and increasing its hardness.

Therefore, it is of interest to study the microhardness of the steel friction surface after frictional interaction with PC based on aromatic polyamide and silica gel. The results of these investigations are shown in Fig. 4b.

As can be seen from the obtained results the introduction of a filler in the polymer (from 0 to $30 \mathrm{wt} \%$ ) contributes to an increase in the microhardness of the steel surface after frictional interaction with the developed PC. It should be noted that the obtained graphical dependence is extreme in the region of $10 \mathrm{wt} \%$ of filler content. Most likely, this can be explained by the formation of a stable cermet coating of the steel sample surface after frictional interaction with PC.

Based on investigations of the morphology and structure of the steel sample surface after friction interaction with developed PC, it can be concluded that the improvement of the tribotechnical characteristics of this friction pair is associated with the formation of a stable antifriction coating that affects the friction and wear of the studied materials. It should be noted that the dependences of the roughness and microhardness of the steel surface of the steel sample on the filler content in PC 
after their frictional interaction are extreme in the filling region of $10 \mathrm{wt} \%$. This correlates with studies of the friction coefficient, temperature on the surface of friction and the intensity of PC linear wear during frictional interaction with steel.

For further studies of the effect of the load and sliding speed on the tribotechnical characteristics of the PC-steel friction pair, a material was selected that has the lowest values of the coefficient of friction and the linear wear rate $(90 \%$ aromatic polyamide $+10 \%$ silica gel). The results of these studies are shown in Fig. 5.

It can be seen from the experimental results that the material friction coefficient decreases from 0.36 to 0.27 when the load increases from 0.5 to $1.25 \mathrm{MPa}$, which is

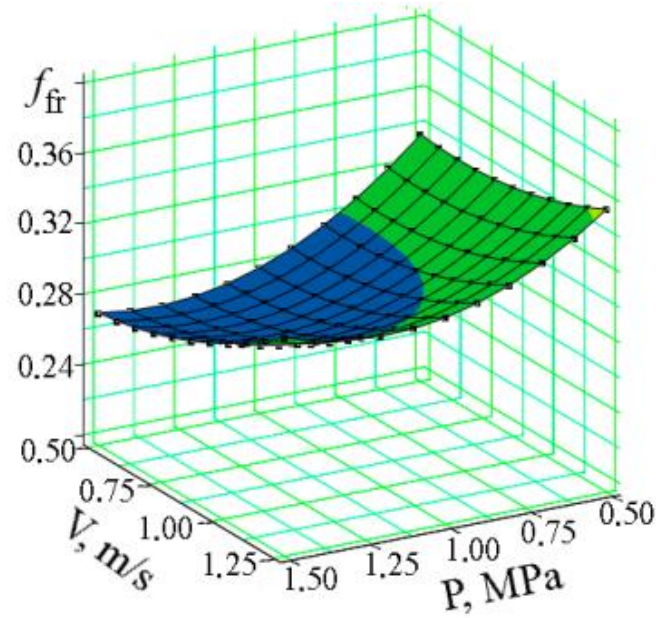

a) typical for antifriction material [27]. A further increase in the load in the friction pair to $1.5 \mathrm{MPa}$ leads to an increase in the friction coefficient to 0.28. An increase in the sliding speed of the studied friction pair contributes to a slight change in the coefficient towards large values, which are associated with the intensification of frictional heating of the friction unit.

The linear wear rate of the studied friction pair changes toward larger values with increasing values of load and sliding speed in the range from 0.5 to $1.5 \mathrm{MPa}$ and from 0.5 to $1.25 \mathrm{~m} / \mathrm{s}$, respectively. In this case, it is worth paying attention to the fact that the load has a greater influence on the parameter under study than the sliding speed.

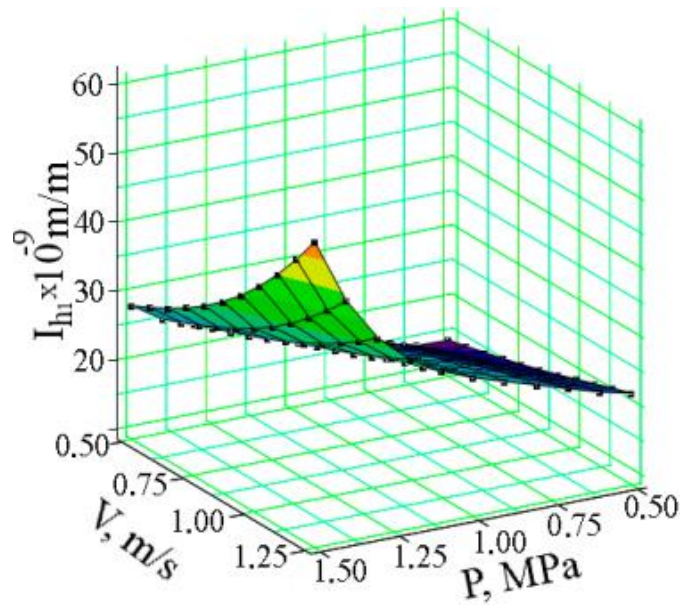

b)

Fig. 5. Dependences of the variation of the coefficient of friction (a) and intensity (b) of the linear wear rate $\left(\mathrm{I}_{\mathrm{h} 1}\right)$ of the material $(90 \%$ aromatic polyamide $+10 \%$ silica gel $)$ on load $(P)$ and sliding speed $(V)$ with friction interaction with steel

Based on the nature of the obtained dependencies, it can be concluded that the PC-steel friction pair under study in the load range of $0.5-1.25 \mathrm{MPa}$ and sliding speed range of $0.5-1 \mathrm{~m} / \mathrm{s}$ works in normal mode. A further increase in these parameters leads to a significant increase in the coefficient of friction and wear rate, which indicates the onset of emergency operation in which there is an intense destruction of the rubbing materials and a possible jamming of the friction unit.

To simplify the determination of the basic tribological properties of a material containing $90 \%$ aromatic polyamide $+10 \%$ silica gel during friction on steel, mathematical dependences of the friction coefficient and linear wear rate on the load and sliding speed in the friction unit under study were obtained. These dependencies are given below:

$$
\begin{gathered}
f_{f r}=0.1 P^{2}+0.064 V^{2}+0.038 P \cdot V-0.284 P- \\
-0.104 V+0478 \\
I_{h 1}=16 P^{2}+5.6 V^{2}+19.52 P \cdot V-29.28 P- \\
-12.6 V+26.65
\end{gathered}
$$

Formulas 1 and 2 can be used not only to find the coefficient of friction and the linear wear rate of PC during frictional interaction with steel in the studied ranges of load and sliding speed $(P=0.5-1.5 \mathrm{MPa}$; $V=0.5-1.25 \mathrm{~m} / \mathrm{s}$ ), but also for predicting the behavior of a friction pair under external operating conditions that go beyond the boundaries of the investigated interval.

It is necessary to establish the effect of silica gel on the level of physical, mechanical and thermal properties of the material with the best values of tribological properties $(90 \%$ aromatic polyamide $+10 \%$ silica gel $)$. The research results are shown in the Table. 
Physical, mechanical and thermal properties of the aromatic polyamide and PC based on it

\begin{tabular}{|l|c|c|}
\hline \multirow{2}{*}{\multicolumn{1}{|c|}{ Property }} & \multicolumn{2}{|c|}{ Material } \\
\cline { 2 - 3 } & $\begin{array}{c}100 \% \\
\text { aromatic polyamide }\end{array}$ & $\begin{array}{c}90 \% \text { aromatic polyamide }+ \\
10 \% \text { silica gel }\end{array}$ \\
\hline Density $\rho, \mathrm{kg} / \mathrm{m}^{3}$ & 1330 & 1350 \\
\hline Hardness $H B, \mathrm{MPa}$ & 205 & 234 \\
\hline Stress at yield strength $\sigma_{y}, \mathrm{MPa}$ & 242 & 245 \\
\hline Elastic modulus $E, \mathrm{MPa}$ & 3000 & 3328 \\
\hline Temperature of heat resistance $T_{D}, \mathrm{~K}$ & 623 & 630 \\
\hline Vicat softening temperature $T_{V C}, \mathrm{~K}$ & 545 & 547 \\
\hline
\end{tabular}

It was found that the introduction of $10 \mathrm{wt} \% \mathrm{wt}$ in aromatic polyamide allows to increase the level of the studied physical, mechanical and thermal properties. Thus, hardness, stress at yield strength and elastic modulus increase to 234,245 and $3328 \mathrm{MPa}$, and the temperature of heat resistance and the Vicat softening temperature to 630 and $547 \mathrm{~K}$, respectively. The increase in these parameters is associated with the physical and chemical interaction of aromatic polyamide with silica gel during the processing of the polymer composition based on them into products.

\section{Conclusions}

As a result of the work, PC based on aromatic polyamide and silica gel were obtained. Based on tribological studies it was found that the optimal filler content in the polymer matrix is $10 \mathrm{wt} \%$. The morphology and structure of the steel surface of friction after friction interaction with the developed PC were studied. It was established that the improvement of the tribotechnical characteristics of the PC-steel friction pair is associated with the formation of an antifriction coating on the steel surface that affects the friction and wear of the studied friction pair. The boundary values of loads (1.5 MPa) and sliding speed (up to $1.25 \mathrm{~m} / \mathrm{s}$ ) were established, at which a PC-steel friction pair will work in normal mode. Based on the results of these investigations the mathematical dependences of the friction coefficient and the intensity of linear wear on the load and sliding speed in the friction pair were derived. The physical, mechanical and thermal properties of the material with the best values of tribological properties $(90 \%$ aromatic polyamide $+10 \%$ silica gel) were investigated. It was established that the introduction of silica gel into an aromatic polyamide leads to an increase in the strength and thermal properties of the obtained PC by $10-12 \%$ in comparison with the initial polymer.

\section{References}

[1] Wang H., Barrett M., Duane B.: Mater. Sci. Eng. B, 2018, 228,

167. https://doi.org/10.1016/j.mseb.2017.11.016

[2] Chiechi R., Havenith R., Hummelen J. et al.: Mater. Today, 2013,

16, 281. https://doi.org/10.1016/j.mattod.2013.07.003

[3] Kabat O., Sytar V., Yermachenko D. et al.: Zbirnik Nauk. Prats

Dniprovskogo Nats. Univ. O. Gonchara, 2017, 23, 40.

[4] Pixiang L., Meyer J., Vaezian B., Polycarpou A.: Wear, 2016, 354,

10. https://doi.org/10.1016/j.wear.2016.02.013

[5] Belyiy V., Ludema K., Myishkin N. et al.: Tribologiya:

Issledovaniya i Prilozheniya: Opyt SShA i stran SNG, Mashinostroyeniye, Moskva 1993.

[6] Balyakin V., Hatipov S., Pilla K.: Trenie i Iznos, 2015, 36, 448.

[7] Li J., Zeng S., Liu S. et al.: Friction, 2020, 8, 301.

https://doi.org/10.1007/s40544-018-0253-3

[8] Kabat O., Sitar V., Suhiy K.: Polimernyi Zh., 2017, 4, 248.

[9] Burya A., Naberezhnaya O.: J. Frict. Wear, 2016, 37, 259.

https://doi.org/10.3103/S106836661603003X

[10] Kabat O., Sytar V., Sukhyy K.: Chem. Chem. Technol., 2018, 12, 326. https://doi.org/10.23939/chcht12.03.326

[11] Su C., Xue F., Xu F. et al.: J. Macromol. Sci. B, 2019, 58, 603. https://doi.org/10.1080/00222348.2019.1614276

[12] Lee L.-H. (Ed.): Polymer Wear and its Control. ACS 1985. https://doi.org/10.1021/bk-1985-0287

[13] Burya A., Chigvintseva O., Suchilina-Sokolenko S.: Polyarylaty. Sintez, Svoistva, Kompozitsionnyie Materialy, Nauka i obrazovaniye, Dnepropetrovsk 2001.

[14] Sorokin A., Goroshkov M., Naumkin A. et al.: Aviatsionnye Materialy i Tekhnologii, 2018, 1, 32.

https://doi.org/10.18577/2071-9140-2018-0-1-32-38.

[15] Tsyiritorov Ts., Andreeva T., Peksimov O. et al.: Uspekhi v

Khimii i Khimicheskoi Tekhnologii, 2018, 11, 137.

[16] Kabat O., Kobelchuk Yu., Chervakov D., Chervakov O.: Science Technology Innovation, 2018, 2, 48.

http://nti.ukrintei.ua/?page_id=1431\&lang=en

[17] Pilato L.: Phenolic Resins: A Century of Progress, Springer,

Berlin 2010. https://doi.org/10.1007/978-3-642-04714-5

[18] Kurta S.: Napovnyuvachi - Sintez, Vlastivosti ta Vykorystannia. Vydavnytstvo Prykarp. Natsion. Univer. im. V. Stefanyka, IvanoFrankivsk 2012.

[19] Zhang D., Sun X., Dang K. et al.: Materials, 2018, 11, 642. https://doi.org/10.3390/ma11040643

[20] Li D., Xie Y., Li W. et al.: Sci. World J., 2013, 320837.

https://doi.org/10.1155/2013/320837

[21] Gogoleva O., Petrova P., Popov S., Ohlopkova A.: Trenie i Iznos, 2015, 36, 301 . 
[22] Burya A., Lipko E., Tomina A.-M.: Inzhenernye Nauki, 2017, 1 122 .

[23] Kabat O., Harchenko B., Derkach A. et al.: Voprosy Khimii i Khimicheskoi Tekhnologii, 2019, 3, 116.

[24] Ayatollahi M., Monfared R., Isfahani R.: Proc. Inst. Mech. Eng. L-J. Mater. Des. Appl., 2019, 233, 874.

https://doi.org/10.1177\%2F1464420717714345

[25] Kabat O., Sytar V., Mitrohin A.: Tehnologicheskie Systemy, $2017,2,25$.

[26] Sitar V., Kabat O.: Voprosy Khimii i Khimicheskoi Tekhnologii, 2005, 1, 199.

[27] Belyiy V., Sviridenok A., Petrokovets M., Savkin V.: Trenie i Iznos Materialov na Osnove Polimerov, Nauka i tekhnika, Minsk 1976.

Received: September 09, 2020 / Revised: October 26, 2020 / Accepted: January 30, 2021

\section{ПОЛІМЕРНІ КОМПОЗИЦІЙНІ МАТЕРІАЛИ ТРИБОТЕХНІЧНОГО ПРИЗНАЧЕННЯ З ВИСОКИМ РІВНЕМ ФІЗИКО-МЕХАНІЧНИХ ТА ТЕПЛОФІЗИЧНИХ ВЛАСТИВОСТЕЙ}

Анотація. Розроблені полімерні композиційні матеріали (ПКМ) триботехнічного призначення з високим рівнем фізико-механічних та теплофізичних властивостей на основі ароматичного поліаміду та силікагелю. Визначені закономірності, які описують вплив вмісту наповнювача у ПКМ на коефіиієнт тертя, температуру на поверхні тертя та інтенсивність лінійного зношування пари тертя ПКМ-сталь. Встановлено, шо оптимальним вмістом силікагелю у полімерній матриці є $10 \%$ мас. Проведені дослідження морфологї̈ сталевої поверхні тертя після фрикиійної взаємодї̈ з ПКМ на основі ароматичного поліаміду і силікагелю. Визначено, шо на сталевій поверхні тертя створюється антифрикиійна плівка, яка сприяє зменшенню коефіцієнту тертя, температури на поверхні тертя та інтенсивності лінійного зношування ПКМ, шуо досліджували. Визначено вплив навантаження та швидкості ковзання на основні трибологічні характеристики пари тертя ПКМ-сталь. Отримані математичні залежності, які описують вплив основних зовнішніх чинників (навантаження та швидкість ковзання) на тертя та зношування пари тертя, щуо досліджували. Проведені фізико-механічні та теплофізичні дослідження розробленого ПКМ та встановлено, що введення у полімерну матрицю $10 \%$ мас. силікагелю сприяє ï 5-10\% покрашченню.

Ключові слова: вузол тертя, ароматичний поліамід, силікагель, полімерний композит, трибологічні властивості, фізико-механічні властивості. 